\title{
High risk human papillomavirus prevalence and genotype distribution among women infected with HIV in Manaus, Amazonas
}

Monique Figueiredo Teixeira ${ }^{1 * \dagger}$, Meritxell Sabidó ${ }^{2,3+}$, André Luiz Leturiondo ${ }^{4}$, Cynthia de Oliveira Ferreira ${ }^{4}$, Kátia Luz Torres ${ }^{5}$ and Adele Schwartz Benzaken ${ }^{4,6,7+}$

\begin{abstract}
Background: Human immunodeficiency virus (HIV)-positive women have a high prevalence of human papillomavirus (HPV), and are infected with a broader range of HPV types than HIV-negative women. We aimed to determine the prevalence of cervical cytologic abnormalities, high-risk (HR)-HPV prevalence, type distribution according to the severity of cervical lesions and CD4 cell count and identify factors associated with HR-HPV infection among women living with HIV in Manaus, Amazonas.
\end{abstract}

Methods: We enrolled 325 women living with HIV that attended an infectious diseases referral hospital. Each woman underwent a gynecological exam, cervical cytology, HR-HPV detection by Polymerase chain Reaction (PCR) using the BD Onclarity ${ }^{\text {TM }}$ HPV Assay, colposcopy and biopsy, when necessary. We assessed the associations between potential risk factors and HR-HPV infection.

Results: Overall, 299 (92.0\%) women had a PCR result. The prevalence of HR-HPV- infection was 31.1\%. The most prevalent HR-HPV types were: 56/59/66 (32.2\%), 35/39/68 (28.0\%), 52 (21.5\%), 16 (19.4\%), and 45 (12.9\%). Among the women with HR-HPV infection ( $n=93), 43.0 \%$ had multiple infections. Women with HPV infection showed higher prevalence of cervical abnormalities than that HPV-negative (LSIL: $22.6 \%$ vs. $1.5 \%$; HSIL: $10.8 \%$ vs. $0.0 \%$ ). The prevalence of HR-HPV among women with cytological abnormalities was $87.5 \%$ for LSIL and $100.0 \%$ for HSIL. Women with CD4 $<200$ cell/ $/ \mathrm{mm}^{3}$ showed the highest HR-HPV prevalence (59.3\%) although this trend was not statistically significant ( $p$-value $=0.62$ ). The mean CD4 cell count decreased with increasing severity of cervical lesions ( $p$-value $=0.001$ ). The multivariable analysis showed that increasing age was associated with a decreased risk of HR-HPV infection with an adjusted prevalence odds ratio of 0.9 (95.0\% Cl: 0.9-1.0, $p$-value: 0.03) for each additional year. The only factor statistically significant associated with HR-HPV infection was CD4 cell count.

Conclusions: HR-HPV and abnormal cytology prevalence are high among women in the Amazonas. The low CD4 cell count was an important determinant of HPV infection and abnormal cytological findings. HPV quadrivalent vaccination used in Brazil might not offer protection for an important fraction of HPV-related disease burden in women living with HIV. This is partly explained by the high presence of non targeted vaccine HR-HPVs, such as the HPV genotype groups 56/59/66, 35/39/68 and individually HPV-52 and HPV-45, some of which contribute to high-grade lesion.

Keywords: Human papillomavirus, Human immunodeficiency virus, Prevalence, Cytology, Polymerase chain reaction

\footnotetext{
* Correspondence: monickft@hotmail.com

${ }^{\dagger}$ Equal contributors

'Universidade Federal do Amazonas (UFAM), 6200, Coroado I, General

Rodrigo Octávio Ave, Manaus, Amazon 69080-900, Brazil

Full list of author information is available at the end of the article
} 


\section{Background}

Infection with human papilloma virus (HPV) is the main cause of cervical cancer [1]. In Brazil, it is estimated that approximately $10.7 \%$ of women in the general population with normal cytology have cervical HPV infection [2]. In the state of Amazonas, HPV has been shown to be the most prevalent sexually transmitted infection (STI) in the population [3].

Young women are the most affected by HPV and by multiple infections. The prevalence tends to decrease with increasing age [4]. A high viral load and the persistence of oncogenic HPV types are progression factors for precancerous lesions and cervical cancer [5]. Additional factors might influence the development of precursor lesions or cancer, such as those related to immunity, genetics and sexual behaviour. In women over 30 years, HPV infection tends to be more persistent than in younger women [6].

Women living with HIV have a higher prevalence of HPV infection with high-risk oncogenic (HR-HPV) multiple infections. Immunosuppression resulting from HIV increases the risk of developing squamous intraepithelial lesions when compared with the general population [7-10]. Patients more severely immunocompromised as a result of HIV infection might have a higher incidence and persistence of lesions caused by HPV [8].

It is also possible that adherence to highly active antiretroviral therapy (HAART) is associated with decreased development of precursor lesions of cervical cancer and improved clearance of HPV infection, increasing survival of women living with HIV with a consequent decrease in cases of cervical cancer [11].

In Amazonas, Brazil, there are few data on the epidemiology of HPV and related cancers and the impact of HIV on these conditions. The objective of this study was to estimate the prevalence of cervical HPV infection and the frequency of genotypes, according to the severity of cervical lesions and CD4 cell counts and identify factors associated with HPV infection in women living with HIV/AIDS that attended a reference hospital for HIV/ AIDS in Manaus, Amazonas.

\section{Methods}

\section{Study design}

A cross-sectional study was conducted for HR-HPV screening in women living with HIV/AIDS that attended an outpatient HIV reference service within a tertiary care hospital (FMT-HVD). This teaching hospital attends most of the HIV/AIDS cases in the Amazon state (95.0\%). This reference hospital is the unique ART provider in the Amazonas state. The study was performed from May 2014 to February 2015.

\section{Study participants}

Women who had a confirmed HIV diagnosis and consecutively sought a gynecological visit to perform routine cytology in the HIV outpatient service of the FMT-HVD hospital were eligible for the study. Women were included if older than 18 years of age, agreed to sign the consent form, were not pregnant and did not have a contraindication for Pap smear examination (i.e., current use of vaginal ovules, menstruation, vaginal clean-up during the last $24 \mathrm{~h}$. In case of contraindication they were rescheduled after conditions were resolved. Hysterectomized women were excluded.

In this study, we aimed to include 323 women living with HIV, based on a prevalence of HPV infection in women living with HIV/AIDS of $65.2 \%$, [12] with $80.0 \%$ power and assuming a $5.0 \%$ level of significance.

\section{Data and sample collection}

After signing the consent form, a nurse interviewed women using a structured questionnaire. The questionnaire included items on sociodemographic, clinical, behavioural, reproductive health and HIV history, including current antiretroviral therapy (ART) use and previous change in ART regimen, and current STI signs and symptoms. Data on CD4 cell counts $\left(\right.$ cells $/ \mathrm{mm}^{3}$ ) and detectable viral load (copies/mL), and nadir CD4 cell count (cells/ $\mathrm{mm}^{3}$ ) were obtained from electronical medical records of the hospital. However, when the last determination had been undertaken more than three months before enrolment, a blood sample was collected.

The participants underwent a gynecological evaluation and two samples of cervical cells were collected. The first sample was taken for conventional cytology using a long Ayres's spatula for subsequent processing at the hospital. The second sample was collected with a cervical brush (Rovers Cervex-Brush Combi ${ }^{\oplus}$, Rovers Medical Devices B.V. Oss, the Netherlands) and introduced into SUREPATH ${ }^{\odot}$ Preservative Fluid (TriPath Imaging, Burlington, NC). Samples were transported on the same day at room temperature to the Fundação Centro de Controle de Oncologia (FCECON) laboratory, where $1 \mathrm{~mL}$ of each sample was stored at $-80{ }^{\circ} \mathrm{C}$ until they were shipped for HPV determination.

\section{Cervical cytology}

Cervical cytology samples were processed at the Department of Pathology of the FMT-HVD. The smears were stained with the Papanicolaou stains and the 2001 Bethesda system was used for classification of cytology results [13]. Cytology examination was carried out under blinded conditions and independently of HPV detection results in PCR by two cytopathologists. A third 
cytopathologist evaluated discordant results, and if discordancy persisted, agreement was reached between the three.

\section{HPV detection and typing}

Samples for HR-HPV determination were shipped to the Instituto de Câncer do Estado do São Paulo (ICESP). They were processed using the BD Onclarity ${ }^{\mathrm{max}}$ HPV Assay (BD Diagnostics, Sparks, MD), which can detect 14 HR-HPV genotypes by simultaneous identification of the HR types $16,18,31,45,51,52$, and due to the limits of this test, other HR genotypes reported by genotype group (33/58; 56/59/66; 35/39/68). The BD Onclarity ${ }^{\text {ma }}$ HPV Assay has shown good performance when compared with Hybrid Capture 2, with specificity ranging from 50.3 to $95.2 \%$ and sensitivity from 95.2 to $98.0 \%$ $[14,15]$. Molecular testing was performed using the automated BD Viper ${ }^{\text {Tu }}$ LT System (BD Diagnostics, Sparks, MD). HR-HPV detection was carried out under blinded conditions with regard to subjects' characteristics and cytology results.

\section{Data analysis}

Data were analyzed using Stata 10.0 (StataCorp LP, College Station, TX). Data were described using percentages and medians with interquartile ranges (IQR), as appropriate. Prevalence and $95.0 \%$ confidence interval (CI) were calculated. The results were categorized according to CD4 cell counts $\left(<200 ; 200-499 ; \geq 500\right.$ cells $\left./ \mathrm{mm}^{3}\right)$. Comparisons between HR-HPV infected and noninfected women were formally carried out using for categorical variables the $\mathrm{X}^{2}$ test, and for continuous variables, the student- $t$ test or the Fisher exact test (when expected frequencies were less than 5), or the U-Mann Whitney test (for non-parametric variables). To ascertain associations between potential risk factors and HR-HPV infection, prevalence odds ratios (pOR) were calculated with their corresponding 95.0\% CI. For the multivariate analysis, pOR were calculated by multiple logistic regression modelling that included covariates for potential confounders, and for factors that were statistically significant $(p<0.1)$ at univariate analysis. All tests were two-tailed and the $p$-value less than 0.05 was considered statistically significant.

The agreement for the blinded and independently cytology reading was measured through the percentage of overall agreement, the percentage of positive agreement, percentage of negative agreement, and the prevalenceadjusted bias-adjusted (PABA)-kappa coefficient, by lesion severity.

\section{Ethics}

The study was approved by the Ethical Institutional Review Board of FMT-HVD (number: 466/2012). Patients gave their signed consent to participate. All women were informed about conventional cytology and HR-HPV detection results. Colposcopy and biopsy were performed following recommendations of the Brazilian Ministry of Health [16]. The study is reported following the STROBE statement and using its checklist for cross-sectional studies [17].

\section{Results}

\section{Study population description}

A total of 331 women were pre-screened and all agreed to participate in the study. Among these, six were excluded because no HIV positive result could be documented in the medical record. Thus, the total number of participants available for analysis was 325 . Their median age was 40.7 years (IQR: 33.1-46.2). A total of 299 women living with HIV had a valid PCR result and 324 a valid result in conventional cytology. The median CD4 cell count with IQR among ART users and ART-naïve when HIV was diagnosed was 321 (173-487) and 620 (422-739). The median (IQR) CD4+ cell count among ART users and patients not on ART was 257 (133-283) and 197.5 (88-314.5), respectively.

Table 1 shows the socio-demographic, risk behaviour, reproductive health and HIV history, and current sexually transmitted infections signs and symptoms. Women living with HIV with an HR-HPV-positive result were younger than those with HR-HPV-negative results (median in years: 38.8 vs. $41.1, p$-value $=0.3$ ). A higher proportion of those with an HR-HPV-positive result had not performed previously cervical cytologies than those with an HR-HPV-negative result $(75.0 \%$ vs. $25.0 \%$, $p$-value $=0.02)$, and most frequently had CD4 cells with counts $<200$ cells $/ \mathrm{mm}^{3}$ than women with HP-HPVnegative result $(40.7 \%$ vs. $59.3, p$-value $=0.001)$. In general, in each age group, women with a CD4 cell count $<200$ cells $/ \mathrm{mm}^{3}$ had a higher HR-HPV prevalence than women with higher CD4 cell counts, although 95.0\% CI was large, suggesting a small number In the CD4 cell count $<200$ cells $/ \mathrm{mm}^{3}$ category.

\section{HR-HPV prevalence, associated factors, and genotype distribution by age and CD4 cell count category}

The results of the PCR screening showed that 93 out of 299 women were infected with HR-HPV, resulting in a prevalence of $31.1 \%$ (95.0\% CI: 25.8-36.4). The distribution of age specific HR-HPV prevalence ranged from $25.4 \%$ in the age group $31-35$ years to $43.5 \%$ in those aged $>50$ years. The proportion seemed to increase from 36 years onwards, peaking at older women (Fig. 1) although this pattern was not statistically significant ( $p$-value $=0.07)$. HR-HPV prevalence by CD4 cell group was $23.8 \%$ in those with CD $4>500 \mathrm{cell} / \mathrm{mm}^{3}, 34.2 \%$ in $200-499 \mathrm{cell} / \mathrm{mm} 3$ and $59.3 \%$ in $<200 \mathrm{cell} / \mathrm{mm}^{3}$. The proportion increased with decreasing CD4 cell count, 
Table 1 Description of population characteristics and results of bivariable and multivariable analysis for risk factors related to HR-HPV infection among women living with HIV in Manaus, Amazonas

\begin{tabular}{|c|c|c|c|c|c|c|}
\hline Variables & $\begin{array}{l}\text { HR-HPV negative } \\
n=206 \text { N (\%) } \\
\text { Median (IQR) }\end{array}$ & $\begin{array}{l}\text { HR-HPV positive } \\
n=93 \mathrm{~N}(\%) \\
\text { Median (IQR) }\end{array}$ & $\begin{array}{l}\text { Crude pOR } \\
(95.0 \% \mathrm{Cl})\end{array}$ & $p$-value & $\begin{array}{l}\text { Adjusted pOR } \\
(95.0 \% \mathrm{Cl})\end{array}$ & $p$-value \\
\hline \multicolumn{7}{|l|}{ Sociodemographic } \\
\hline Age in years $(N=299)$ & $41.1(45.9-33.5)$ & $38.8(31.2-44.4)$ & $0.9(0.9-1.0)$ & 0.03 & $0.9(0.9-1.0)$ & 0.03 \\
\hline$\leq 34$ & $56(27.2)$ & $35(37.6)$ & 1 & & & \\
\hline $35-39$ & $30(14.6)$ & $18(19.3)$ & $1.0(0.5-2.0)$ & 0.91 & $\ldots$ & $\ldots$ \\
\hline $40-44$ & $55(26.7)$ & $18(19.4)$ & $0.5(0.3-1.0)$ & 0.27 & $\ldots$ & \\
\hline$\geq 45$ & $65(31.5)$ & $22(23.7)$ & $0.5(0.3-1.0)$ & 0.06 & $\ldots$ & $\ldots$ \\
\hline \multicolumn{7}{|l|}{ Civil status $(N=299)$} \\
\hline Married/cohabitating & $133(64.6)$ & $50(53.8)$ & 1 & & & \\
\hline Single/not cohabitating & $73(35.4)$ & $43(46.2)$ & $1.5(0.9-2.5)$ & 0.08 & $\ldots$ & $\ldots$ \\
\hline \multicolumn{7}{|l|}{ Level of education $(N=299)$} \\
\hline$<$ Primary school & $42(20.4)$ & $25(26.8)$ & 1 & & & \\
\hline At least primary school & $164(79.6)$ & $68(73.2)$ & $1.4(0.8-2.5)$ & 0.21 & $\ldots$ & $\ldots$ \\
\hline \multicolumn{7}{|l|}{ Currently working $(N=299)$} \\
\hline Yes & $83(40.3)$ & $31(33.3)$ & 1 & & & \\
\hline No & $123(59.7)$ & $62(66.7)$ & $1.3(0.8-2.2)$ & 0.25 & $\ldots$ & $\ldots$ \\
\hline \multicolumn{7}{|c|}{ Sexual behaviour and other risk behaviour } \\
\hline \multicolumn{7}{|l|}{ Current smokers $(N=299)$} \\
\hline No & $191(92.7)$ & $88(94.6)$ & 1 & & & \\
\hline Yes & $15(7.3)$ & $5(5.4)$ & $0.7(0.2-2.0)$ & 0.54 & $\ldots$ & $\ldots$ \\
\hline \multicolumn{7}{|c|}{ Age at first sex (years) $(N=297)$} \\
\hline$\leq 15$ & $108(52.4)$ & $44(48.4)$ & $0.8(0.5-1.3)$ & 0.52 & $\ldots$ & $\ldots$ \\
\hline$>15$ & $98(47.6)$ & $47(51.6)$ & 1 & & & \\
\hline \multicolumn{7}{|c|}{ Sexual partners in life to date $(N=297)$} \\
\hline$<4$ & $60(29.3)$ & $28(30.4)$ & 1 & & & \\
\hline 4 to 7 & $65(31.7)$ & $32(34.8)$ & $1.0(0.5-1.9)$ & 0.87 & $\ldots$ & $\ldots$ \\
\hline$\geq 8$ & $80(39.0)$ & $32(34.6)$ & $0.8(0.4-1.5)$ & 0.62 & $\ldots$ & $\ldots$ \\
\hline \multicolumn{7}{|c|}{ Regular partner currently ( $N=299$ ) } \\
\hline Yes & $148(71.8)$ & $62(66.7)$ & 1 & & & \\
\hline No & $58(28.2)$ & $31(33.3)$ & $1.2(0.7-2.1)$ & 0.37 & $\ldots$ & $\ldots$ \\
\hline \multicolumn{7}{|c|}{ Condom use at last sex with regular partner $(N=210)$} \\
\hline Yes & $107(72.3)$ & $45(72.6)$ & 1 & & & \\
\hline No & $41(27.7)$ & $17(27.4)$ & $0.9(0.5-1.9)$ & 0.97 & $\ldots$ & \\
\hline \multicolumn{7}{|c|}{ Occasional sex partner currently ( $N=299)$} \\
\hline No & $184(89.3)$ & $82(88.2)$ & 1 & & & \\
\hline Yes & $22(10.7)$ & $11(11.8)$ & $1.1(0.5-2.4)$ & 0.78 & $\ldots$ & $\ldots$ \\
\hline \multicolumn{7}{|c|}{ Condom use at last sex with occasional partner $(N=33)$} \\
\hline Yes & $16(72.7)$ & $8(72.7)$ & 1 & & & \\
\hline No & $6(27.3)$ & $3(27.3)$ & $1.0(0.2-5.0)$ & 1.00 & $\ldots$ & $\ldots$ \\
\hline \multicolumn{7}{|c|}{ Reproductive and sexual health } \\
\hline \multicolumn{7}{|c|}{ Current oral contraceptive use $(N=299)$} \\
\hline Yes & $202(98.1)$ & $90(96.7)$ & 1 & & & \\
\hline No & $4(1.9)$ & $3(3.3)$ & $1.6(0.3-7.6)$ & 0.50 & $\ldots$ & $\ldots$ \\
\hline
\end{tabular}


Table 1 Description of population characteristics and results of bivariable and multivariable analysis for risk factors related to HR-HPV infection among women living with HIV in Manaus, Amazonas (Continued)

\begin{tabular}{|c|c|c|c|c|c|c|}
\hline Variables & $\begin{array}{l}\text { HR-HPV negative } \\
n=206 \mathrm{~N}(\%) \\
\text { Median (IQR) }\end{array}$ & $\begin{array}{l}\text { HR-HPV positive } \\
n=93 \mathrm{~N}(\%) \\
\text { Median (IQR) }\end{array}$ & $\begin{array}{l}\text { Crude pOR } \\
(95.0 \% \mathrm{Cl})\end{array}$ & $p$-value & $\begin{array}{l}\text { Adjusted pOR } \\
(95.0 \% \mathrm{Cl})\end{array}$ & $p$-value \\
\hline \multicolumn{7}{|l|}{ Previous cervical cytology $(N=299)$} \\
\hline Yes & $204(99.0)$ & $87(93.6)$ & 1 & & & \\
\hline No & $2(1.0)$ & $6(6.4)$ & $7.0(1.3-35.5)$ & 0.02 & $\ldots$ & $\ldots$ \\
\hline \multicolumn{7}{|l|}{ Ever had an STI $(N=299)$} \\
\hline No & $146(70.9)$ & $65(69.9)$ & 1 & & & \\
\hline Yes & $60(29.1)$ & $28(30.1)$ & $1.0(0.6-1.7)$ & 0.86 & $\ldots$ & $\ldots$ \\
\hline \multicolumn{7}{|l|}{ Parity $(N=299)$} \\
\hline Nulliparous & $11(5.3)$ & $10(10.8)$ & 1 & & & \\
\hline 1 to 3 & $97(47.0)$ & $39(41.9)$ & $0.4(0.1-1.1)$ & 0.09 & $\ldots$ & $\ldots$ \\
\hline$\geq 4$ & $98(47.7)$ & $44(47.3)$ & $0.4(0.2-1.2)$ & 0.14 & $\ldots$ & $\ldots$ \\
\hline \multicolumn{7}{|l|}{ Ever had an abortion $(N=278)$} \\
\hline No & $90(46.2)$ & $44(53.0)$ & 1 & & & \\
\hline Yes & $105(53.8)$ & $39(47.0)$ & $0.7(0.4-1.2)$ & 0.30 & $\ldots$ & $\ldots$ \\
\hline \multicolumn{7}{|l|}{ HIV history } \\
\hline Time since HIV diagnosis in years $(\mathrm{N}=298)$ & $6(3-10)$ & $5(2-10)$ & $0.9(0.9-1.0)$ & 0.53 & $\ldots$ & $\ldots$ \\
\hline CD4 cell count nadir ${ }^{\mathrm{b}}(N=294)$ & $195(83-317)$ & $221(86-357)$ & $1.0(0.9-1.0)$ & 0.90 & $\ldots$ & $\ldots$ \\
\hline CD4 cells $/ \mathrm{mm}^{3 a}(\mathrm{~N}=298)$ & $348(197-550)$ & $322(162-491)$ & $0.9(0.9-1.0)$ & 0.30 & & \\
\hline$\geq 500$ & $115(56.1)$ & $36(38.7)$ & 1 & & 1 & \\
\hline 200-499 & 79 (38.5) & $41(44.1)$ & $1.6(0.9-2.8)$ & 0.06 & $1.6(0.9-2.8)$ & 0.06 \\
\hline$<200$ & $11(5.4)$ & $16(17.2)$ & $4.7(2.0-11.3)$ & $<0.001$ & $4.7(2.0-11.3)$ & $<0.001$ \\
\hline Detectable viral load (copies $/ \mathrm{mL})^{\mathrm{a}}(N=298)$ & $6049(390-32,000)$ & $11,112.5(1070-43,258.5)$ & $1.0(0.9-1.0)$ & 0.60 & & \\
\hline \multicolumn{7}{|l|}{ Current ART $(N=299)$} \\
\hline Yes & $185(89.8)$ & $78(83.9)$ & 1 & & & \\
\hline No & $21(10.2)$ & $15(16.1)$ & $1.6(0.8-3.4)$ & 0.14 & $\ldots$ & $\ldots$ \\
\hline \multicolumn{7}{|l|}{ Previous change in ART regimen $(N=270)$} \\
\hline No & $119(62.9)$ & $44(54.3)$ & 1 & & & \\
\hline Yes & $70(37.1)$ & $37(45.7)$ & $1.4(0.8-2.4)$ & 0.18 & $\ldots$ & $\ldots$ \\
\hline
\end{tabular}

ART Antiretroviral therapy, CI Confidence interval, IQR Interquartile range, $p O R$ Prevalence odds ratio, SD Standard deviation, STI Sexually transmitted infection, $p$-value < 0.05: statistically significant

${ }^{a}$ Most recent blood test collected within 3 months before enrolment

$\mathrm{b}_{\text {It }}$ is the lowest CD4 cell count of the patient

although this pattern was not statistically significant ( $p$-value $=0.62)$.

The most prevalent HR-HPV types among 93 HRHPV-positive and HIV positive women were HPV pool56/59/66 (32.3\%), HPV-35/39/68 (28.0\%) and isolated HPV-52 (21.5\%), HPV-58 (20.4\%), HPV-16 (19.4\%), HPV-45 (12.9\%), HPV-31 (11.8\%), and HPV-18 (2.2\%) (Fig. 2). Multiple infections (range: 2-4 types) were identified in 40 of 93 women (43.0\%). The prevalence of women with multiple HR-HPV infections was $13.4 \%$ (40/299) (95.0\% CI: 9.5\%-17.3). Among cases of multiple infection $(N=40)$, the prevalence of HPV-16 was $27.5 \%(n=11)$, of HPV-18 was $5.0 \%(n=2)$ and of HPV-52 was $35.0 \%(n=14)$. Multiple infections had a higher HR-HPV prevalence in older age groups (41-45 years: $18.9 \%$; $46-50$ years: $18.9 \%$; > 50 years: $17.4 \%)$ than in younger age groups $(<26$ years: $7.3 \%$; $26-30$ years: $13.2 \%$; $31-35$ years: $11.9 \%)$ but no trend with age was found ( $p$-value $=0.10)$.

When compared with HR-HPV-negative women, those with a HR-HPV-positive result were younger, a lower proportion had undertaken a cervical cytology ever, had a lower median CD4 cell count at last determination, and a higher proportion had CD4 cell count $<200 \mathrm{cell} / \mathrm{mm}^{3}$ (Table 1). Results from the multivariable analysis showed that increasing age was associated with a decreased risk of HR-HPV infection with an adjusted pOR of 0.9 (95.0\% CI: $0.9-1.0, p$-value $=0.03)$ for each additional year. The only 


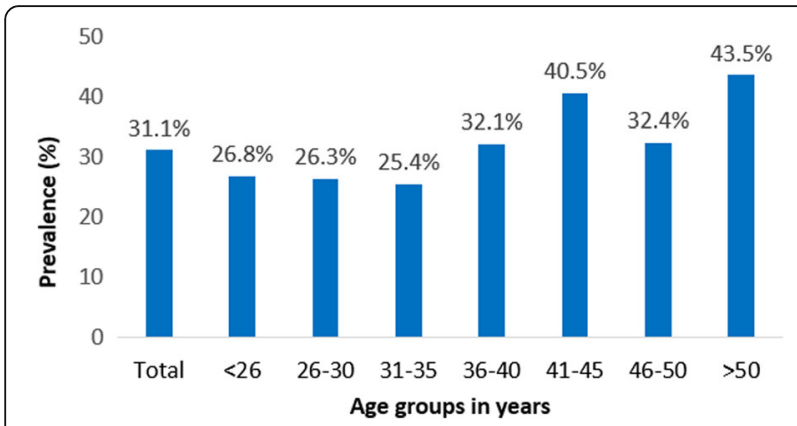

Fig. 1 Prevalence of HPV infection according to age among 299 women living with HIV in Manaus, Amazonas

factor statistically significant associated with HR-HPV infection was CD4 cell count: women with CD4 cell count $<200 \mathrm{cell} / \mathrm{mm}^{3}$ had an pOR of having HR-HPV that was 4.7 (95.0\% CI: 2.0-11.3, $p$-value <0.001) times greater than that of women with CD4 cell count $\geq 500$ cells $/ \mathrm{mm}^{3}$.

\section{Relationship between HR-HPV infection, conventional cytology results, and CD4 cell counts}

Overall, $84.2 \%$ (275) of women had a normal cytology, 2.7\% (9) ASCUS, 1.7\% (5) ASC-H, 8.1\% (25) LSIL, 3.4\% (10) HSIL, and no cancer cases. The proportion of cytological abnormalities was higher in women with HR-HPV-positive than in women with a negative HRHPV-result. (Additional file 1: Table S1).

By cytological grade, the prevalence of HR-HPV was $37.5 \%$ in ASC-US, $80.0 \%$ in ASC-H, $87.5 \%$ in LSIL, and $100.0 \%$ in HSIL. The prevalence of HR-HPV increased with the degree of cytological abnormalities, ranging from $21.9 \%$ among women with normal cytology to $100.0 \%$ among women with HSIL ( $p$-value for trend
$<0.0001)$. The same pattern was observed by decreasing CD4 cell count groups (Table 2).

HPV- 56/59/66 (either 56, 59, 66 or any combination of these three types) was the most prevalent genotype (52.3\%) among 21 HR-HPV-positive women with LSIL and the most prevalent one (60.0\%) among $10 \mathrm{HR}-\mathrm{HPV}$ positive women with HSIL in a total of 93 women coinfected with HR-HPV and HIV (Table 3). The second most common genotypes for LSIL were HPV-16 (23.8\%) and HPV-35/39/68 (23.8\%), whereas for HSIL HPV-16 was found in half $(50.0 \%)$ of these women. None of the women with LSIL and HSIL were infected with HPV-18. The prevalence of HR HPV genotype increased by cytological grade in HPV-16, HPV-31, HPV-45, HPV-33/58, and HPV- single infection and multiple infection ( $p$-value for trend $<0.001)$, and in HPV-52 ( $p$-value for trend $=0.04$ ).

Compared to those with single infections, women with multiple HR-HPV infections had a higher prevalence of LSIL $(42.9 \%$ vs. $57.1 \%, p<0.001)$ and HSIL $(20.0 \%$ vs. $80.0 \%, \mathrm{p}<0.001)$. In women with multiple HR-HPV infections, the degree of severity of cytological lesions was strongly correlated with a decreased CD4 cell count (Additional file 1: Table S2).

Figure 3 shows that in the HSIL category, women with CD4 counts $\geq 500 \mathrm{cell} / \mathrm{mm}^{3}$ had a lower proportion of multiple HR-HPV-infections (50.0\%) than those with CD4 $200-499 \mathrm{cell} / \mathrm{mm}^{3}(80.0 \%)$ and those with $\mathrm{CD} 4<200 \mathrm{cell} / \mathrm{mm}^{3}$ (100.0\%).

The overall agreement for conventional cytology observed between the blinded first and second evaluators was $89.0 \%$. By type of lesion, it was $>90.0 \%$ and the PABA-kappa statistic ranged from 0.82-0.97 (Additional file 1: Table S3).

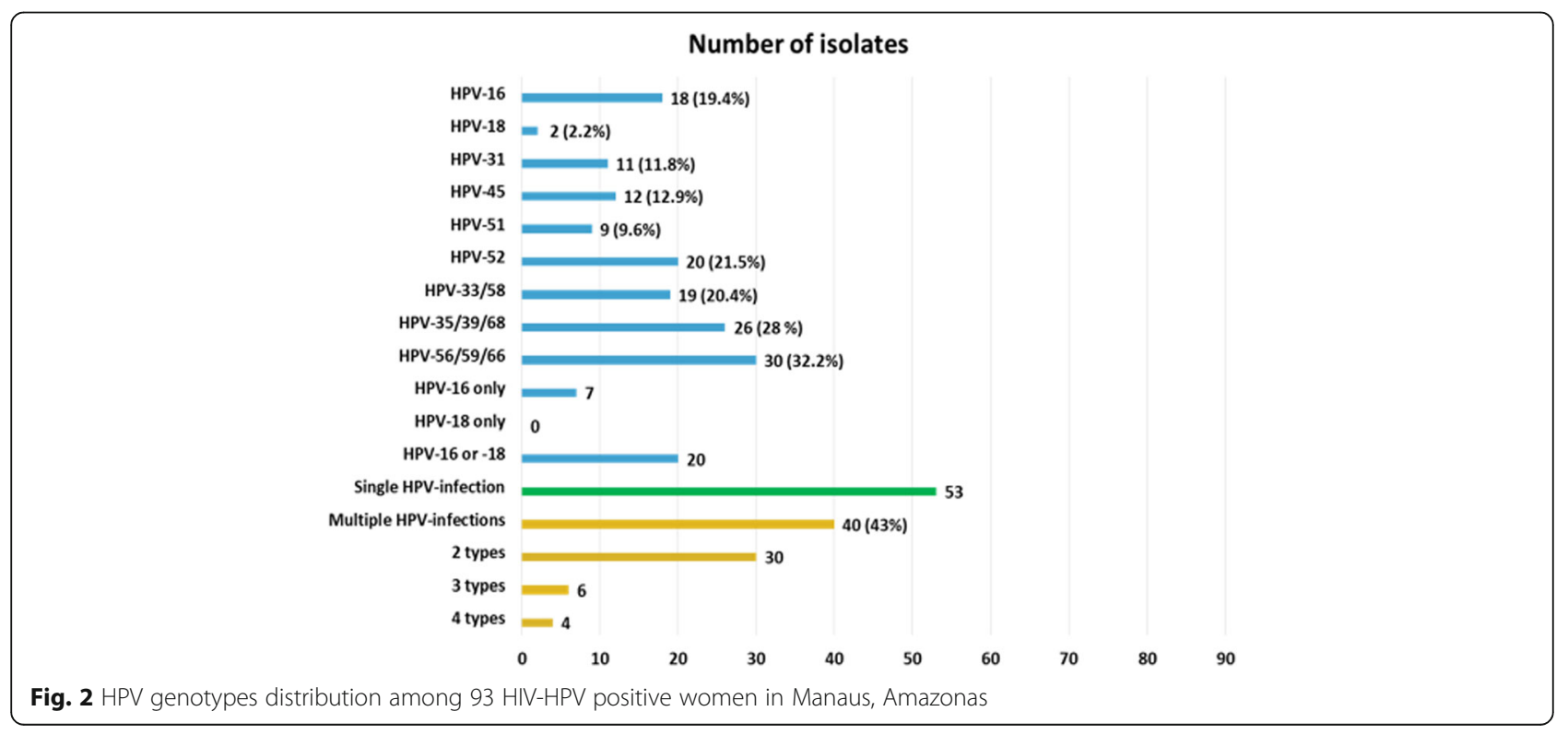


Table 2 HR-HPV prevalence as determined by PCR, according to the cytological findings and HIV viral load among women living with HIV in Manaus, Amazonas

\begin{tabular}{lllll}
\hline $\begin{array}{l}\text { HR-HPV Prevalence } \\
\text { Cytology }\end{array}$ & General & CD4 $\geq 500 \mathrm{cell} / \mathrm{mm}^{3}$ & CD4 200-499 cell/mm & CD4<200 cell/mm \\
\hline Unsatisfactory & 0 & 0 & 0 & 0 \\
Normal & $55 / 251(21.9)$ & $27 / 139(19.4)$ & $20 / 94(21.3)$ & $8 / 17(47.1)$ \\
ASC-US & $3 / 8(37.5)$ & $1 / 1(100)$ & $1 / 4(25)$ & $1 / 3(33.3)$ \\
ASC-H & $4 / 5(80.0)$ & $2 / 2(100)$ & $2 / 3(66.7)$ & 0 \\
LSIL & $21 / 24(87.5)$ & $4 / 6(66.7)$ & $13 / 14(92.9)$ & $4 / 4(100)$ \\
HSIL & $10 / 10(100)$ & $2 / 2(100)$ & $5 / 5(100)$ & $3 / 3(100)$ \\
\hline
\end{tabular}

ASC-H Atypical Squamous Cells of Undetermined Significance, when it is not possible to disregard high degree lesions; ASC-US Atypical Squamous Cells of Undetermined Significance, LSIL Low-grade Squamous Intraepithelial Lesions, HSIL High-grade Squamous Intraepithelial Lesions, HR-HPV High Risk Human Papillomavirus

\section{Discussion}

This study provides evidence about the prevalence of HR-PV infection, their associations, and cervical lesions among women living with HIV, an area of research with scarce literature from the Amazonas.

The prevalence of HR-HPV infection found, $31.1 \%$, is approximately half of that found in another study in HIV positive women in Amazonas (61.6\%) [18]. This discrepancy could be explained because in the latter study women were younger (median age: 32 years [IQR]: 27-38, vs. 40.7 years [IQR]: $33.1-46.2$ ) and a peak among younger women has been described in a number of countries [19]. In the same study, women had a lower median CD4 cell count at enrolment (338.5 [IQR: 211.5-513.3] cells/ $\mathrm{mm}^{3}$ vs. 504.0 [IQR: $321.0-676.5$ ), which can limit the clearance of the virus, and $16.0 \%$ of women were commercial sex workers, which is a highly HPV exposed population [20]. Other studies in Brazil involving HIV positive women have found higher prevalence of HR-HPV from $35.7 \%$ to $98.0 \%[12,21-24]$. The differences with the results from other studies might be partly explained by information bias. Indeed, the study design used does not allow to differentiate between prevalent, incident and persistent HR-HPV infection leading to misclassification of the infection status and limiting comparability of our estimates with those from other studies.

We found that $43.0 \%$ of HR-HPV-infected women had multiple infections, which is in agreement with other Brazilian, ranging from $32.2 \%$ to $64.8 \%$ [24-27] and ranged from $52.0 \%$ to $64.3 \%$ in international studies [28, 29]. Women living with HIV are more likely to harbor multiple HPV infection than immunocompetent women [30] which is associated with an increased risk of intraepithelial neoplasia and of cancer [31, 32]. This probably reflects the effect of HIV-induced immunosuppression [33] rather than sexual risk behaviour [34].

In the present study, we found a wide diversity regarding HR-HPV types and their distribution, with HPV-52, HPV-16 and HPV-45 being the most frequent individual types. However, this needs to be taken with caution because the PCR method used did not allow the measurement for all individual genotypes and the various

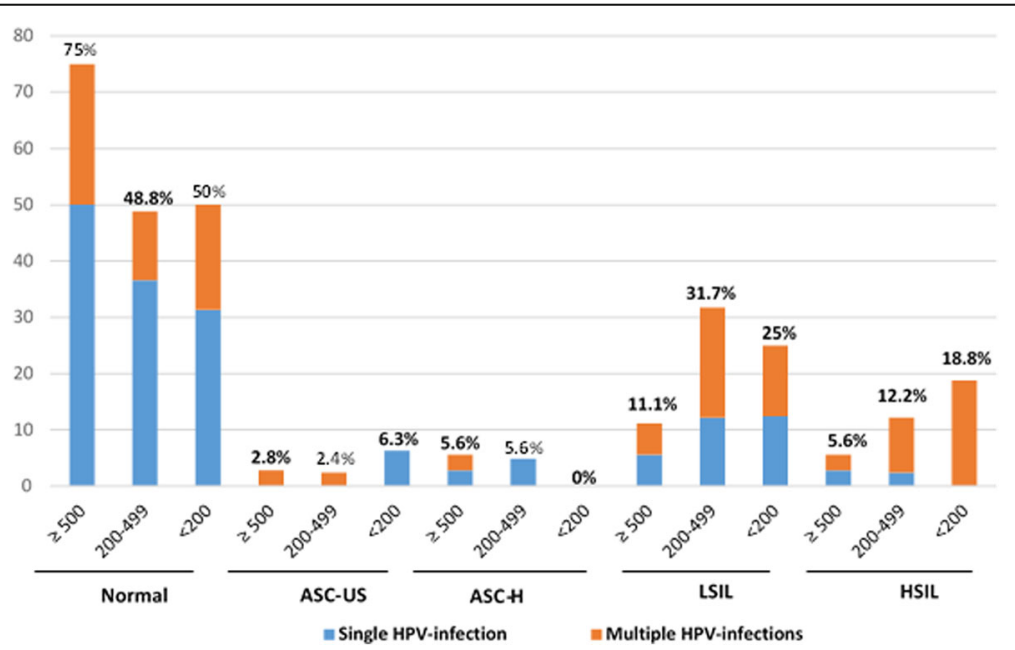

Fig. 3 Prevalence of HPV infection according to CD4 counts and cytology and distribution of multiple HPV infections from 93 HIV-HPV positive women in Manaus, Amazonas 
Table 3 Distribution of HR-HPV genotype according to cytology results in 93 HPV-HIV positive women in Manaus, Amazonas

\begin{tabular}{|c|c|c|c|c|c|c|}
\hline & Normal $(n=55)$ & ASC-US $(n=3)$ & ASC-H $(n=4)$ & LSIL $(n=21)$ & $\mathrm{HSIL}(n=10)$ & $p$-test for trends \\
\hline HPV-16 & $6(10.9)$ & $1(33.3)$ & $1(25.0)$ & $5(23.8)$ & $5(50.0)$ & $<0.001$ \\
\hline HPV-18 & $1(1.8)$ & $0(0.0)$ & $1(25.0)$ & $0(0.0)$ & $0(0.0)$ & 0.30 \\
\hline HPV-31 & $4(7.3)$ & $0(0.0)$ & $1(25.0)$ & $4(19.0)$ & $2(20.0)$ & $<0.001$ \\
\hline HPV-45 & $4(7.3)$ & $0(0.0)$ & $1(25.0)$ & $4(19.0)$ & $3(30.0)$ & $<0.001$ \\
\hline HPV-51 & $6(10.9)$ & $1(33.3)$ & $0(0.0)$ & $2(9.5)$ & $0(0.0)$ & 0.17 \\
\hline HPV-52 & 13 (23.6) & $0(0.0)$ & $1(25.0)$ & $3(14.3)$ & $3(30.0)$ & 0.04 \\
\hline HPV-33/58 & $9(16.4)$ & $2(66.7)$ & $1(25.0)$ & $4(19.0)$ & $3(30.0)$ & $<0.001$ \\
\hline HPV-35/39/68 & 17 (30.9) & $1(33.3)$ & $0(0.0)$ & $5(23.8)$ & $3(30.0)$ & 0.05 \\
\hline HPV-56/59/66 & $18(32.7)$ & $0(0.0)$ & $0(0.0)$ & $11(52.3)$ & $6(60.0)$ & 0.05 \\
\hline HPV-16 only & $4(7.3)$ & $0(0.0)$ & $1(25.0)$ & $0(0.0)$ & $2(20.0)$ & 0.44 \\
\hline HPV-18 only & $0(0.0)$ & $0(0.0)$ & $0(0.0)$ & $0(0.0)$ & $0(0.0)$ & 0.30 \\
\hline HPV-16 or -18 & $7(12.7)$ & $1(33.3)$ & $2(50.0)$ & $5(23.8)$ & $5(50.0)$ & 0.40 \\
\hline HPV- single infection & $38(69.1)$ & $1(33.3)$ & $3(75.0)$ & $9(42.9)$ & $2(20.0)$ & $<0.001$ \\
\hline HPV- multiple infection & $17(30.9)$ & $2(66.7)$ & $1(25.0)$ & $12(57.1)$ & $8(80.0)$ & $<0.001$ \\
\hline 2 types & $13(23.6)$ & $2(66.7)$ & $1(25.0)$ & $9(42.9)$ & $5(50.0)$ & $\ldots$ \\
\hline 3 types & $2(3.6)$ & $0(0.0)$ & $0(0.0)$ & $1(4.8)$ & $3(30.0)$ & $\ldots$ \\
\hline 4 types & $2(3.6)$ & $0(0.0)$ & $0(0.0)$ & $2(9.5)$ & $0(0.0)$ & $\ldots$ \\
\hline
\end{tabular}

$p$-value $<0.05$ : statistically significant

groupings of HPV types difficult the interpretation. As an example, the high prevalence of HPV-35/39/68 might be driven by HPV-35 alone and this type has been implicated in HSIL and invasive cervical cancer in women living with HIV $[35,36]$. Women living with HIV are characterized by a wide variation of HPV genotypes, probably related to their sexual behaviour and the reactivation of latent infections, which can facilitate infection by different HPV genotypes. Contrary to what most studies suggest, $[10,12,21$, 28, 30, 37-39] HPV-16 was not the most common HPV type. This is in line with the results from other studies among indigenous populations in the Amazonas, [40] among women living with HIV in Brazil, [26] in the USA [29] and in Africa, [41] that corroborate our findings and place HPV-16 as not the most common type detected. It has been suggested that the contribution of HPV-16 correlates inversely with the overall HPV prevalence [42]. This pattern is explained by a higher prevalence of other HPV types in areas where HPV is extremely common, and the increase is not explained by the contribution of any other single type. Nevertheless, HPV-16 was the most prevalent individual HPV type among HSIL lesions, which is consistent with the results of a meta-analysis that included 19,883 women living with HIV from 86 studies worldwide [36]. This meta-analysis reported that HPV-16 positivity tended to increase with severity of cervical lesions. In Africa, HPV-16 accounts for $31.1 \%$ of HSIL and 46.6\% of invasive cervical cancers. In Latin America, HPV-16 accounts for $37.5 \%$ of HSIL with no data available for invasive cervical cancers [36].
A low number of cases of HPV-18 were detected although it ranks amongst the top positions in most regions [37, 39]. In addition, HPV-18 accounts for a high proportion of HPV-positive in HSIL and invasive cervical cancers among women living with HIV [36]. Likewise, in other studies involving women living with HIV the HPV-18 contribution has been low [21, 24, 43-45]. It has either not been commonly detected in Brazilian studies $[46,47]$ or has shown a prevalence below $1.0 \%$ in asymptomatic women [48-50]. In two studies conducted in the Amazon region HPV-18 was not detected [37, 39]. It is unlikely that the low prevalence of HPV-18 found is related with the PCR method used. The BD Onclarity assay used showed good performance when compared with standard genotyping test [14, 15]. For HPV-18 (single or multiple infection), the agreement with the GP5+/6+ LMNX assay was high, with a kappa of 0.93 (95.0\% CI: 0.87-0.99) [51].

Age-specific HR-HPV distribution presented as a unimodal distribution skewed to the left although this pattern was not statistically significant. Although there are studies that indicate a higher prevalence of HPV in younger women, $[4,52-55]$ we observed a higher prevalence of HR-HPV prevalence among older women (> 50 years) which has also been described in some other studies [10, 19, 32, 56-58]. It has been suggested that the increase in the perimenopause period may be due to higher rates of HPV persistence and recurrence at older ages rather than new HPV acquisition, [59] and that viral characteristics such as HPV type and 
variants, [60] weakened immune system, changes in sexual behaviour during middle age (both for men and women [61]), or previous individual screening practices, may play a role [56]. The association between younger age and higher prevalence of HR-HPV is probably due to the presence of transient infections in this group of women; however, this association is generally observed in non-HIV infected women but is not consistent in women living with HIV/AIDS [62].

In multivariable analysis, increasing age presented only borderline association with an increasing risk of presenting HR-HPV. We did not observe a peak of prevalence among young women $(<26$ years) which might be explained because only $13.0 \%$ in our sample were $<26$ years and among them, only 11 (27.0\%) were infected with HR-HPV.

In the present study we found a clear association between weakened immune status and infection by HRHPV. In most studies of HIV and HPV, the magnitude of increased HPV prevalence was proportional to the severity of immunosuppression $[10,18,38,63-65]$. While many HPV infections are transient, women living with HIV are more likely to have persistent HPV infections, [66] and in other studies the frequency of persistence varied inversely with CD4 cell count $[62,65]$. These results suggest that HIV induced immunosuppression might cytological findings was $21.9 \%$, higher than the global estimate of $16.1 \%$ reported a meta-analysis for women in the general population from Latin America [42]. We found a high prevalence of LSIL (8.1\%) and HSIL (3.4\%) that reflects long-term persistent infections, in concordance with the high rates of multiple infections observed among HPV infected with these lesions [10, $25,55]$. Our results are consistent with other studies in which the presence of HPV in cytology with abnormal results ranged from $71.0 \%$ to $90.0 \%$ for LSIL [10, 67], and between $80.6 \%$ to $100.0 \%$ for HSIL [10, 30, 67]. Worsening of immune status was correlated with severity of lesions, as previously described [68].

We found high diversity of HR-HPV types in women with abnormal cytology results. In our study, most cytological alterations were related to types 16,31 and 45 . HPV-16 was the most common type in HSIL, which has been reported in a meta-analysis of HIV positive women with HSIL, [30] and in women from the general population [32]. Half of the HSIL cases presented HPV-16, which has high oncogenic potential and its presence is affected by the immunology status of the patient. The high prevalence of HR-HPV non-targeted by current vaccines does not reduce the importance of vaccination against HPV-16 and -18 , proven genotypes with the highest carcinogenic potential. Furthermore, cross-protection has been described for HPV-45 and HPV-31 [69]. However, newer vaccines such as the nonavalent $H P V$ vaccine present the possibility of better coverage for women [70-72].
This study has some limitations. It did not include a truly population-based design, as study participants were recruited from a reference hospital. However, this hospital attends to $95.0 \%$ of HIV patients from the Amazonas. Our sample included women who had a prolonged history of HIV infection (median 6 years), most were taking HAART (87.9\%), had previously cytology (97.2\%), had a relatively immune competence status (median CD4 cell count $504.0 \mathrm{cell} / \mathrm{mm}^{3}$ ), and median age was 40.7 years. These women could have a higher self-care standard, higher accessibility to health care and better health, which would result in underestimating the true HR-HPV prevalence in the population. In addition, we did not measure variables such as nutrition and behaviour of male partners that can influence HPV DNA detection [73-75]. The BD Onclarity ${ }^{\mathrm{Ta}}$ HPV Assay used for PCR does not allow a measurement for all individual genotypes. The various groupings of HPV types are difficult to interpret. It was not possible to investigate associations of duration of ART and the results of HR-HPV and cervical lesion, since the duration of ART would not be accurate given that treatment interruptions was not collected. Regarding the study size, the background estimate used was based on Brazilian studies [12, 22, 23] (ranging from $63.0 \%$ to $98.0 \%$ ) but was higher than those reported in international studies. In addition, the statistical power was low at $80.0 \%$. These reasons might have influenced the accuracy of the estimates measured and the strength of the association in the multivariable model. This study has a cross sectional design which allows only for presentation of baseline information.

\section{Conclusions}

In conclusion, we found a high prevalence of HR-HPV infection and cervical lesions among women living with HIV in Amazonas. We found a wide diversity of HR-HPV genotypes, being the most common ones individually HPV-52, HPV-16 and HPV-45, although the highest prevalence was found in the genotype groups 56/59/66 and 35/39/68. HPV-16 and HPV-18 were less common than other HPV types but $50.0 \%$ of women with HSIL had HPV-16. The most important determinant of HPV infection was a low CD4 cell count. Most abnormal cytological findings were observed in women with poor immunological status. HPV quadrivalent vaccination used in Brazil might not offer protection for an important fraction of HPV-related disease burden in women living with HIV given the high prevalence of non-targeted vaccine HRHPV, some of which (eg. 35, 39, 45, 56) contribute to highgrade lesions. Newer vaccines such as the nonavalent HPV vaccine [70-72] present the possibility of better coverage for women and will need to be evaluated. Strengthening preventive efforts is necessary to improve early detection through increasing accessibility to screening programs, adherence to follow-up among those with lesions, and intensifying health education for women living with HIV. 


\section{Additional file}

Additional file 1: Table S1. Prevalence of conventional cytology results according to HPV status and CD4 counts among 298 women living with HIV in Manaus, Amazonas. Table S2 Association between cytological lesions and CD4 cell counts among women living with HIV in Manaus, Amazonas. Table S3 Agreement between blinded observers in the independent reading of conventional cytology by type of lesion (DOCX $19 \mathrm{~kb}$ )

\begin{abstract}
Abbreviations
AOR: Adjusted Odds Ratio; ASC-H: Atypical Squamous Cells of Undetermined Significance, when it is not possible to disregard high degree lesions; ASC-US: Atypical Squamous Cells of Undetermined Significance; CD4: Molecule that is expressed on the surface of some T cells; Cl: Confidence Interval; FCECON: Fundação Centro de Controle de Oncologia; HAART: Highly Active Antiretroviral Therapy; HIV: Human Immunodeficiency Virus; HPV: Human Papillomavirus; HR-HPV: High Risk HPV; HSIL: High-grade Squamous Intraepithelial Lesions; ICESP: Instituto de Câncer do Estado do São Paulo; LSIL: Low-grade Squamous Intraepithelial Lesions; OR: Odds Ratio; PCR: Polymerase Chain Reaction; SD: Standard Deviation; STI: Sexually Transmitted Infection
\end{abstract}

\section{Acknowledgments}

The authors would like to thank Dr. Luiz Carlos de Lima Ferreira, Dr. José de Ribamar Araújo, Dra. Rosilene Viana Andrade, Dr. Edson de Freitas Gomes, Dra. Ivanete de Lima Sampaio and Dra. Francisca Andrade de Queiroz, the team of pathology that read the cytology results, and Dra. Rosieny Santos Batalha, the gynecologist at FMT-HVD, Dr. José Eduardo Levi and Dr. Toni Ricardo Martins who performed the molecular analyzes, Heidy Halanna de Melo Farah Rondon and Vanessa Santarém who prepared the slides for liquid cytology, Jeana Rodrigues Benezar, Klyssia Godinho Silva and Elaine Cristina Anselmo Pedreno for the assistance during the inclusion of subjects in the study and all the women living with HIV that agreed to participate in the study.

\section{Funding}

This study had funding approved in the edict 009/2011 PRONEM of FAPEAM.

\section{Availability of data and materials}

Please contact author for data requests.

\section{Authors' contributions}

MFT participated in the drafting of the study, inclusion of subjects of the research and data collection, analysis and interpretation of the data and writing of the manuscript. MS participated in drafting the study, analysis and interpretation of data, writing of the manuscript and critical review of the manuscript. ALL participated in molecular biology data analysis and critical review of the manuscript. COF participated in the analysis of molecular biology data and critical review of the manuscript. KLT participated in the analysis of molecular biology data and supervision in the preparation of slides and storage of samples and critical review of the manuscript. ASB participated in drafting the study, analysis and interpretation of the data, writing the manuscript and critical review of the manuscript. All authors read and approved the final manuscript.

\section{Ethics approval and consent to participate}

Name of Ethics Committee: Fundação de Medicina Tropical Dr. Heitor Vieira Dourado (FMT-HVD).

Researcher: Monique Figueiredo Teixeira.

Research Title: HPV: HPV: Qual a melhor método diagnóstico laboratorial para mulheres com HIV/Aids? (What is the best laboratory diagnostic method for women with HIV/AIDS?)

Proposed Institution: Diretoria de Ensino e Pesquisa - DENPE Version: 1. CAAE: 26,652,314.9.0000.0005.

Opinion Number: 625.561

Date of the Rapporteur: 04/11/2014.

Main Sponsor: Fundação de Amparo à Pesquisa do Estado do Amazonas FAPEAM.

\section{Consent for publication}

Not applicable.

\section{Competing interests}

The authors declare that they have no competing interests.

\section{Publisher's Note}

Springer Nature remains neutral with regard to jurisdictional claims in published maps and institutional affiliations.

\section{Author details}

${ }^{1}$ Universidade Federal do Amazonas (UFAM), 6200, Coroado I, General Rodrigo Octávio Ave, Manaus, Amazon 69080-900, Brazil. ${ }^{2}$ TransLab. Departament de Ciències Mèdiques, Facultat de Medicina, Girona, Catalunya, Spain. ${ }^{3}$ CIBER de Epidemiología y Salud Pública (CIBERESP), Madrid, Spain. ${ }^{4}$ Fundação Alfredo da Matta (FUAM), Manaus, Amazonas, Brazil. ${ }^{5}$ Fundação Centro de Controle de Oncologia do Amazonas (FCecon), Manaus, Amazonas, Brazil. ${ }^{6}$ Fundação de Medicina Tropical Dr. Heitor Vieira Dourado (FMT-HVD), Manaus, Amazonas, Brazil. ${ }^{7}$ Departamento de IST, Aids, e Hepatites Virais, Ministério da Saúde, Brasília, DF, Brazil.

Received: 4 September 2017 Accepted: 1 February 2018

Published online: 17 February 2018

\section{References}

1. Jemal A, Bray F, Ferlay J. Global cancer statistics. CA Cancer J Clin. 2011; 61(2):69-90.

2. ICO Information Centre on HPV and Cancer. Brazil: Human Papillomavirus and Related Cancers, Fact Sheet 2017 [Internet]. 19 april 2017. Available from: http://www.hpvcentre.net/statistics/reports/BRA_FS.pdf.

3. Pedrosa VL, Galban E, Benzaken A, Vasquez FG, Izan Jr. JL. DST e suas Determinantes: Quatro Anos de Vigilância em um Centro Sentinela no Estado do Amazonas - Brasil. J Bras Doenças Sex Transm [Internet]. 2011 [cited 2013 Oct 18];23(2):57-65. Available from: http://www.dst.uff.br/ revista23-2-2011/3-DST\%20e\%20suas\%20Determinantes\%20Quatro\%20Anos \%20de\%20Vigilancia.pdf.

4. Argyri E, Papaspyridakos S, Tsimplaki E, Michala L, Myriokefalitaki E, Papassideri I, et al. A cross sectional study of HPV type prevalence according to age and cytology. BMC Infect Dis [Internet]. 2013 Jan;13:53. Available from: http://www.pubmedcentral.nih.gov/articlerender.fcgi?artid=3575232\& tool=pmcentrez\&rendertype $=$ abstract.

5. Kim YM, Park JY, Lee KM, Kong T-W, Yoo S-C, Kim WY, et al. Does pretreatment HPV viral load correlate with prognosis in patients with early stage cervical carcinoma? J Gynecol Oncol [Internet]. 2008 Jun [cited 2013 Oct 29];19(2):113-6. Available from: http://www.pubmedcentral.nih.gov/ articlerender.fcgi?artid=2676452\&tool=pmcentrez\&rendertype=abstract.

6. BRASIL. Instituto Nacional de Câncer José Alencar Gomes da Silva. Coordenação de Prevenção e Vigilância. Estimativa 2016: Incidência de câncer no Brasil [Internet]. Ministério da Saúde Instituto Nacional de Cancer José Alencar Gomes da Silva 2016. 124 p. Available from: http://www.inca. gov.br/bvscontrolecancer/publicacoes/edicao/Estimativa_2016.pdf.

7. Kobayashi A, Greenblatt RM, Anastos K, Minkoff H, Massad LS, Young M, et al. Functional attributes of mucosal immunity in cervical intraepithelial neoplasia and effects of HIV infection functional attributes of mucosal immunity in cervical intraepithelial neoplasia and effects of HIV infection. Am Assoc Cancer Res. 2004:6766-74.

8. Zimmermmann JB, Melo VH, de Castro LPF, Alves MJM, Zimmermmann SG, Del Castillo DM. Associação entre a contagem de linfócitos T CD4 + e a gravidade da neoplasia intra-epitelial cervical diagnosticada pela histopatologia em mulheres infectadas pelo HIV. Rev Bras Ginecol Obs. 2006;28(6):345-51.

9. Corrêa CM, Melo VH, Mendez D, Castillo D. Coinfecção HIV-HPV : prevalência e multiplicidade de genótipos do HPV no colo uterino co-infection of HIVHPV : prevalence and multiplicity of HPV genotypes in the cervix uterine. Femina. 2009;37(6):2-7.

10. Stuardo V, Agustí C, Godinez JM, Montoliu A, Torné A, Tarrats A, et al. Human papillomavirus infection in HIV-1 infected women in Catalonia (Spain): implications for prevention of cervical cancer. PLoS One [Internet]. 2012 Jan [cited 2013 Oct 18];7(10):e47755. Available from: http://www. pubmedcentral.nih.gov/articlerender.fcgi?artid=3484159\&tool=pmcentrez \&rendertype $=$ abstract.

11. Minkoff H, Zhong Y, Burk RD, Palefsky JM, Xue X, Watts DH, et al. Influence of adherent and effective antiretroviral therapy use on human papillomavirus infection and squamous intraepithelial lesions in human immunodeficiency 
virus-positive women. J Infect Dis [Internet]. 2010 Mar [cited 2013 Oct 18]; 201(5):681-90. Available from: http://www.pubmedcentral.nih.gov/ articlerender.fcgi?artid $=2818607 \&$ tool=pmcentrez\&rendertype $=$ abstract.

12. Entiauspe LG, Teixeira LO, Mendoza-sassi RA, Gonçalves CV, Gonçalves P, Barral M. Papilomavírus humano : prevalência e genótipos encontrados em mulheres HIV positivas e negativas, em um centro de referência no extremo Sul do Brasil. Rev Soc Bras Med Trop. 2010;43(3):260-3.

13. Solomon D, Davey D, Kurman R, Moriarty A, O'Connor D, Prey M, et al. The 2001 Bethesda System: terminology for reporting results of cervical cytology. JAMA [Internet]. 2002 Apr;24;287(16)):2114-9. Available from: http://www.ncbi.nlm.nih.gov/pubmed/11966386.

14. Bottari F, Sideri M, Gulmini C, Igidbashian S, Tricca A, Casadio C, et al. Comparison of onclarity human papillomavirus (HPV) assay with hybrid capture II HPV DNA assay for detection of cervical intraepithelial neoplasia grade 2 and 3 lesions. J Clin Microbiol [Internet]. 2015;53(7):2109-14. Available from: http://www.scopus.com/inward/record.url?eid=2-s2.084932600747\&partnerlD=40\&md5=c270fa50be7c44a44d960ae0e7b01ee2.

15. Ejegod D, Bottari F, Pedersen H, Sandri MT, Bonde J. The BD Onclarity HPV assay on SurePath collected samples meets the International Guidelines for Human Papillomavirus Test Requirements for Cervical Screening. J Clin Microbiol. 2016; 54(9):2267-72. Available from: http://jcm.asm.org/content/54/9/2267.full.

16. Brasil. Ministério da Saúde. Instituto Nacional de Câncer. Coordenação Geral de Ações Estratégicas. Divisão de Apoio à Rede de Atenção Oncológica. Diretrizes Brasileiras para o Rastreamento do Câncer do Colo do Útero. INCA. 2016.

17. Elm, Von Fl. EM. Checklist of items that should be included in reports of crosssectional studies [Internet]. Strobe statement. 2008 [cited 2014 Jun 3]. p. 3-4. Available from: https:/uww.strobe-statement.org/index.php?id=available-checklists.

18. Silva LCF, Miranda A, Batalha R, Ferreira L, Santos M, Talhari S. High-risk human papillomavirus and cervical lesions among women living with HIV/AIDS in Brazilian Amazon, Brazil. Brazilian J Infect Dis [Internet]. 2015; (x x):5-10. Available from: http://linkinghub.elsevier.com/retrieve/pii/S1413867015001269.

19. Franceschi S, Herrero R, Clifford GM, Snijders PJF, Arslan A, Anh PTH, et al. Variations in the age-specific curves of human papillomavirus prevalence in women worldwide. Int J Cancer. 2006;119(11):2677-84.

20. Vallès X, Murga GB, Hernández G, Sabidó M, Chuy A, Lloveras B, et al. High prevalence of human papillomavirus infection in the female population of Guatemala. Int J Cancer. 2009;125(5):1161-7.

21. Ceccato Junior BPV, Lopes APC, Nascimento LF, Novaes LM, Melo VH. Prevalência de infecção cervical por papilomavírus humano e neoplasia intraepitelial cervical em mulheres HIV-positivas e negativas. Rev Bras Ginecol e Obs [Internet]. 2015;37(4):178-85. Available from: http://www. scielo.br/scielo.php?script=sci_arttext\&pid=S0100-72032015000400178\&lng= pt\&nrm=iso\&tlng=en.

22. Videla S, Darwich L, Cañadas MP, Paredes R, Tarrats A, Castella E, et al. Epidemiological data of different human papillomavirus genotypes in cervical specimens of HIV-1-infected women without history of cervical pathology. J Acquir Immune Defic Syndr [Internet]. 2009;50(2):168-75. Available from: https://journals.Iww.com/jaids/Fulltext/2009/02010/ Epidemiological_Data_of_Different_Human.7.aspx.

23. Levi JE, Kleter B, Quint WG V., Fink MCS, Canto CLM, Matsubara R, et al. High Prevalence of Human Papillomavirus (HPV) Infections and High Frequency of Multiple HPV Genotypes in Human Immunodeficiency Virus-Infected Women in Brazil. J Clin Microbiol [Internet]. 2002 Sep 1 [cited 2013 Dec 17]; 40(9):3341-5. Available from: http://jcm.asm.org/content/40/9/3341.full.

24. Corrêa CM, Teixeira NCP, Araújo ACL. De, Carvalho NDO, Castillo DM del, Campos RR, et al. prevalence and multiplicity of HPV in HIV women in Minas Gerais, Brazil. Rev Assoc med bras [internet], Available from. 2011; 57(4):425-30. http://www.scielo.br/scielo.php?script=sci_arttext\&pid=S010442302011000400017\&lng=en\&nrm=iso\&tlng=en.

25. Campos RR, de Melo VH, del Castilho DM, Nogueira CPF. Prevalência do papilomavírus humano e seus genótipos em mulheres portadoras e nãoportadoras do vírus da imunodeficiência humana. Rev Bras Ginecol Obs. 2005;27(31):248-56.

26. Castilho JL, Levi JE, Luz PM, Cambou MC, Vanni T, de Andrade A, et al. A cross-sectional study of high-risk human papillomavirus clustering and cervical outcomes in HIV-infected women in Rio de Janeiro, Brazil. BMC Cancer [Internet]. 2015;15(1):478. Available from: http://www.biomedcentral. com/1471-2407/15/478.

27. Levi JE, Fernandes S, Tateno AF, Motta E, Lima LP, Eluf-Neto J, et al. Presence of multiple human papillomavirus types in cervical samples from HIV-infected women. Gynecol Oncol. 2004;92(1):225-31.
28. Anastos K, Hoover DR, Burk RD, Cajigas A, Shi Q, Singh DK, et al. Risk factors for cervical precancer and cancer in HIV-infected, HPV-positive Rwandan women. PLoS One [Internet]. 2010 Jan [cited 2013 Oct 18];5(10):e13525. Available from: http://www.pubmedcentral.nih.gov/articlerender.fcgi?artid= 2958122\&tool=pmcentrez\&rendertype $=$ abstract.

29. Luque $A E$, Jabeen $M$, Messing $S$, Lane $C$ a, Demeter $L M$, Rose $R C$, et al. Prevalence of human papillomavirus genotypes and related abnormalities of cervical cytological results among HIV-1-infected women in Rochester, New York. J Infect Dis 2006;194(4):428-434.

30. Clifford GM, Gonçalves MAG, Franceschi S. Human papillomavirus types among women infected with HIV: a meta-analysis. AIDS [Internet]. 2006 Nov 28;20(may 2005):2337-44. Available from: https:/journals.Iww.com/ aidsonline/fulltext/2006/11280/Human_papillomavirus_types_among_ women_infected.10.aspx.

31. Moscicki A-B, Ellenberg JH, Crowley-Nowick P, Darragh TM, Xu J, Fahrat S. Risk of high-grade squamous intraepithelial lesion in HIV-infected adolescents. J Infect Dis. 2004;190(8):1413-21.

32. Herrero R, Castle PE, Schiffman M, Bratti MC, Hildesheim A, Morales J, et al. Epidemiologic profile of type-specific human papillomavirus infection and cervical neoplasia in Guanacaste, Costa Rica. J Infect Dis. 2005;191(11):1796-807.

33. Palefsky J. Biology of HPV in HIV infection. Adv Dent Res. 2006;19:99-105.

34. Strickler HD, Burk RD, Fazzari M, Anastos K, Minkoff H, Massad LS, et al. Natural history and possible reactivation of human papillomavirus in human immunodeficiency virus-positive women. J Natl Cancer Inst. 2005;97(8):577-86.

35. Kelly HA, Ngou J, Chikandiwa A, Sawadogo B, Gilham C, Omar T, et al. Associations of Human Papillomavirus (HPV) genotypes with high-grade cervical neoplasia (CIN2+) in a cohort of women living with HIV in Burkina Faso and South Africa. PLoS One [Internet]. 2017;12(3):1-14. Available from: http://journals.plos.org/plosone/article?id=10.1371/journal.pone.0174117.

36. Clifford GM, Tully S, Franceschi S. Carcinogenicity of human papillomavirus (HPV) types in HIV-positive women: a meta-analysis from HPV infection to cervical cancer. Clin Infect Dis. 2017;64(9):1228-35.

37. Rocha DAP, Barbosa Filho RAA, De Queiroz FA, Dos Santos CMB. High prevalence and genotypic diversity of the human papillomavirus in amazonian women, Brazil. Infect Dis Obstet Gynecol. 2013;(Article ID 514859):5.

38. Heard I, Tassie JM, Schmitz V, Mandelbrot L, Kazatchkine MD, Orth G. Increased risk of cervical disease among human immunodeficiency virusinfected women with severe immunosuppression and high human papillomavirus load(1). Obstet Gynecol. 2000;96(3):403-9.

39. Castro MM, Farias IP, Borborema-Santos CM, Correia G, Astolfi-Filho S. Prevalence of human papillomavirus (HPV) type 16 variants and rare HPV types in the central Amazon region. Genet Mol Res. 2011;10(1):186-96.

40. Fonseca AJ, Taeko D, Chaves TA, Amorim LDDC, Murari RSW, Miranda AE, et al. HPV infection and cervical screening in socially isolated indigenous women inhabitants of the Amazonian rainforest. PLoS One [Internet]. 2015;10(7): e0133635. Available from: http://dx.plos.org/10.1371/journal.pone.0133635.

41. Didelot-Rousseau M-N, Nagot N, Costes-Martineau V, Vallès X, Ouedraogo A, Konate I, et al. Human papillomavirus genotype distribution and cervical squamous intraepithelial lesions among high-risk women with and without HIV-1 infection in Burkina Faso. Br J Cancer [Internet]. 2006;95(3):355-62. Available from: http://www.nature.com/doifinder/10.1038/sj.bjc.6603252.

42. Bruni L, Diaz M, Castellsagué X, Ferrer E, Bosch FX, de Sanjosé S. Cervical human papillomavirus prevalence in 5 continents: meta-analysis of 1 million women with normal cytological findings. J Infect Dis [Internet]. 2010 Dec 15 [cited 2013 Oct 18];202(12):1789-1799. Available from: https://academic.oup. com/jid/article/202/12/1789/2192082.

43. Davis AT, Chakraborty H, Flowers L, Mosunjac MB. Cervical dysplasia in women infected with the human immunodeficiency virus (HIV): a correlation with HIV viral load and CD4+ count. Gynecol Oncol [Internet]. 2001;80(3):350-4. Available from: http://www.gynecologiconcology-online. net/article/S0090-8258(00)96104-3/pdf.

44. Kjaer SK, van den Brule AJ, Bock JE, Poll PA, Engholm G, Sherman ME, et al. Human papillomavirus-the most significant risk determinant of cervical intraepithelial neoplasia. Int J Cancer. 1996;65(5):601-6.

45. Palefsky J. Human papillomavirus-related disease in people with HIV. Curr Opin HIV AIDS [Internet]. 2009;4(1):52-6. Available from: http://www.pubmedcentral. nih.gov/articlerender.fcgi?artid=2756707\&tool=pmcentrez\&rendertype= abstract.

46. Krambeck WM, Cadidé RM, Dalmarco EM, CMM DC. HPV Detection and genotyping as an earlier approach in cervical cancer screening of the female genital tract. Clin Exp Obstet Gynecol. 2008;35(3):175-8. 
47. Ayres ARG, GA e S. Prevalência de infecção do colo do útero pelo HPV no Brasil: revisão sistemática. Rev Saúde Pública. 2010;44(5):963-74.

48. Da Fonseca AJ, Galvão RS, Miranda AE, LC de L F, Chen Z. Comparison of three human papillomavirus DNA detection methods: next generation sequencing, multiplex-PCR and nested-PCR followed by sanger based sequencing. J Med Virol [Internet]. 2015;30(12):1-7. Available from: http:// doi.wiley.com/10.1002/jmv.24413.

49. WHO/ICO. Human Papillomavirus and Related Diseases Report. Hum Papillomavirus Relat Dis Rep [Internet]. 2015;74. Available from: www. hpvcentre.net.

50. Eluf-Neto J, Booth M, Muñoz N, Bosch FX, Meijer CJ, Walboomers JM. Human papillomavirus and invasive cervical cancer in Brazil. Br J Cancer [Internet]. 1994;69(1):114-9. Available from: http://www.ncbi.nlm.nih.gov/ pmc/articles/PMC1968795/.

51. Cuschieri K, Geraets DT, Moore C, Quint W, Duvall E, Arbyn M. Clinical and analytical performance of the onclarity HPV assay using the valgent framework. J Clin Microbiol. 2015:53(10):3272-9.

52. Cuzick J, Clavel C, Petry K-U, Meijer CJLM, Hoyer H, Ratnam S, et al. Overview of the European and North American studies on HPV testing in primary cervical cancer screening. Int J cancer [Internet]. 2006 Sep 1 [cited 2013 Oct 18];119(5):1095-1101. Available from: http://onlinelibrary.wiley. com/doi/10.1002/ijc.21955/full.

53. Coupé VMH, Berkhof J, Bulkmans NWJ, Snijders PJF, Meijer CJLM. Agedependent prevalence of 14 high-risk HPV types in the Netherlands: implications for prophylactic vaccination and screening. Br J Cancer [Internet]. 2008;98(3):646-51. Available from: http://www.nature.com/ doifinder/10.1038/sj.bjc.6604162.

54. Winer RL, Lee SK, Hughes JP, Adam DE, Kiviat NB, L A K. Genital human papillomavirus infection: incidence and risk factors in a cohort of female university students. Am J Epidemiol. 2003;157(3):218-26.

55. Manhart LE, Holmes KK, Koutsky L a, Wood TR, Kenney DL, Feng Q, et al. Human papillomavirus infection among sexually active young women in the United States: implications for developing a vaccination strategy. Sex Transm Dis 2006:33(8):502-508.

56. Sanjosé S, Díaz M, Castellsagué X, Clifford G, Bruni L. Worldwide prevalence and genotype distribution of cervical HPV in women with normal cytology: a meta-analysis. Lancet Infect Dis. 2007;7(July):453-9.

57. Smith JS, Melendy A, Rana RK, Pimenta JM. Age-Specific Prevalence of Infection with Human Papillomavirus in Females: A Global Review. J Adolesc Heal. 2008:43(4 SUPPL)

58. Lazcano-Ponce E, Herrero R, Munoz N, Cruz A, Shah KV, Alonso P, et al. Epidemiology of HPV infection among Mexican women with normal cervical cytology. Int J Cancer [Internet]. 2001;91(3):412-20. Available from: http://onlinelibrary.wiley.com/doi/10.1002/1097-0215(20010201)91:3\%3C412:: AID-IJC1071\%3E3.0.CO;2-M/full.

59. Castle PE, Schiffman M, Herrero R, Hildesheim A, Rodriguez AC, Bratti MC, et al. A prospective study of age trends in cervical human papillomavirus acquisition and persistence in Guanacaste, Costa Rica. J Infect Dis. 2005;191(11):1808-16.

60. Sichero L, Ferreira S, Trottier H, Duarte-Franco E, Ferenczy A, Franco EL, et al. High grade cervical lesions are caused preferentially by non-European variants of HPVs 16 and 18. Int J Cancer. 2007;120(8):1763-8.

61. Bosch FX, Burchell AN, Schiffman M, Giuliano AR, de Sanjose S, Bruni L, et al. Epidemiology and natural history of human papillomavirus infections and typespecific implications in cervical neoplasia. Vaccine. 2008;26(SUPPL. 10):K1-16.

62. Delory T, Ngo-Giang-Huong N, Rangdaeng S, Chotivanich N, Limtrakul A, Putiyanun C, et al. Human papillomavirus infection and cervical lesions in HIV infected women on antiretroviral treatment in Thailand. J Inf Secur. 2017;74(5):501-11.

63. Djigma FW, Ouédraogo C, Karou DS, Sagna T, Bisseye C, Zeba M, et al. Prevalence and genotype characterization of Human Papillomaviruses among HIV-seropositive in Ouagadougou, Burkina Faso. Acta Trop [Internet]. Elsevier B.V. 2011;117(3):202-6. Available from: http://linkinghub.elsevier. com/retrieve/pii/S0001706X10003013.

64. Keller MJ, Burk RD, Anastos K, Massad LS, Minkoff H, Watts DH, et al. Risk of cervical Precancer and cancer and no evidence of oncogenic HPV infection. JAMA. 2012;308(4):362-9.

65. Piper MA, Severin ST, Wiktor SZ, Unger ER, Ghys PD, Miller DL, et al. Association of human papillomavirus with HIV and CD4 cell count in women with high or low numbers of sex partners. Sex Transm Infect. 1999;75(4):253-7.

66. Sun XW, Ellerbrock TV, Lungu O, Chiasson MA, Bush TJ, Wright TC. Human papillomavirus infection in human immunodeficiency virus-seropositive women. Obstet Gynecol. 1995;85(5 I):680-6.
67. Néli Sueli Teixeira de Souza, Victor Hugo do Melo LPF de C. Diagnóstico da Infecção pelo HPV em Lesões do Colo do Útero em Mulheres HIV + : Acuidade da Histopatologia Pacientes e Métodos. Rev Bras Ginecol Obs. 2001; 23(6):355-61.

68. Clifford GM, Franceschi S, Keiser O, Schoni-Affolter F, Lise M, Dehler S, et al. Immunodeficiency and the risk of cervical intra-epithelial neoplasia 2/3 and cervical cancer: a nested case-control study in the Swiss HIV cohort study. Int J Cancer. 2016;1740:1732-40.

69. Bonanni P, Boccalini S, Bechini A. Efficacy, duration of immunity and cross protection after HPV vaccination: a review of the evidence. Vaccine. 2009; 27(SUPPL. 1):46-53.

70. Riethmuller D, Jacquard A-C, Lacau St Guily J, Aubin F, Carcopino X, Pradat $P$, et al. Potential impact of a nonavalent HPV vaccine on the occurrence of HPV-related diseases in France. BMC Public Health [Internet]. 2015;15(1):453. Available from: http://www.pubmedcentral.nih.gov/articlerender.fcgi?artid= 4433025\&tool=pmcentrez\&rendertype=abstract.

71. Van Damme P, Bonanni P, Bosch FX, Joura E, Krüger Kjaer S, Meijer CJLM, et al. Use of the nonavalent HPV vaccine in individuals previously fully or partially vaccinated with bivalent or quadrivalent HPV vaccines. Vaccine [Internet]. Elsevier Ltd. 2016;34(6):757-61. Available from: http://linkinghub. elsevier.com/retrieve/pii/S0264410X15018745.

72. Van De Velde N, Boily MC, Drolet M, Franco EL, Mayrand MH, Kliewer EV, et al. Population-level impact of the bivalent, quadrivalent, and nonavalent human papillomavirus vaccines: a model-based analysis. J Natl Cancer Inst. 2012;104(22):1712-23.

73. Molano M, Posso H, Weiderpass E, AJC $v$ d B, Ronderos M, Franceschi S, et al. Prevalence and determinants of HPV infection among Colombian women with normal cytology. Br J Cancer. 2002;87:324-33.

74. Winer RL, Hughes JP, Feng Q, O'Reilly S, Kiviat NB, Holmes KK, et al. Condom use and the risk of genital human papillomavirus infection in young women. N Engl J med [internet], 2006;354(25):2645-54. Available from: http://www.nejm.org/doi/full/10.1056/NEJMoa053284.

75. Castellsagué $X$, Bosch FX, Muñoz N. The male role in cervical cancer. Salud Publica Mex. 2003;45(SUPPL. 3):345-53.

\section{Submit your next manuscript to BioMed Central and we will help you at every step:}

- We accept pre-submission inquiries

- Our selector tool helps you to find the most relevant journal

- We provide round the clock customer support

- Convenient online submission

- Thorough peer review

- Inclusion in PubMed and all major indexing services

- Maximum visibility for your research

Submit your manuscript at www.biomedcentral.com/submit
Biomed Central 